\title{
Urbanization and Service Delivery Planning: Analysis of Water and Sanitation Management Systems in the City of Harare, Zimbabwe
}

\author{
Loretta Muzondi \\ Lecturer: Department of Development Planning and Management, \\ University of Limpopo, Turfloop Campus \\ loretta.muzondi@ul.ac.za
}

\section{Doi:10.5901/mjss.2014.v5n20p2905}

\begin{abstract}
Urbanization has in recent years epitomized the developing world's human movement landscapes. The increased concentration of populations into developing countries' cities was, however, devoid of the attendant planning for service delivery, with the result that the urban system became incrementally overwhelmed. The resultant conditions have commonly bred social ills ranging from overcrowding, crime, spread of water-borne diseases, dearth of sanitation and deterioration of the urban delivery systems, which are often transposed into the planned sections of the cities. This paper provides an analysis of urbanization experiences in Harare City, Zimbabwe, in order to demonstrate the linkages with disruption of the service delivery systems, poor water supplies, dearth of sanitation and deterioration of waste management. The paper concludes that these social ills are a function of the crisis of urban planning occasioned by misconceptions that manifest in the form of discrepancies between urban development investments and national demographic dynamics.
\end{abstract}

Keywords: Urbanization; Urban Service Delivery Planning; Water and Sanitation Management Systems; Harare City; Zimbabwe

\section{Introduction}

Urbanization has in recent years epitomized the developing world's human movement landscapes (Watson, 2009).In Zimbabwe, urbanization is also not a new phenomenon, soon after the country gained its independence from colonial rule in 1980, scores of people began to move into the capital city, Harare (Hove and Tirimboi, 2011). During the period from 1980 to 2000, the city of Harare had the capacity to absorb the large in-migration population, largely credited to the colonial infrastructure built through discriminatory urban planning. But the city of Harare has been since 2000 experience unprecedented rate of urbanization which is apparently linked to the socio-economic misery in the peri-urban small towns and rural areas (Cohen, 2006). In 2012, Harare City was the largest in terms of national share of population at $16 \%$ (Zimbabwe Central Statistics, 2012). Inevitably, the conglomeration of people into the city, whose economy could not absorb the excess population, created massive urbanization pressure on service delivery management systems. Other consequences included the city being virtually transformed into a haven of social-ills linked to the overcrowding, and population settlement and need for housing ultimately overwhelming the territorial size of the city. Given the resultant squalid living conditions that the majority of the new entrants to the city had to endure, criminal activities mushroomed out of control. Excess population that had no access to services has been blamed for running down the infrastructure of the city because people who could not secure cash income and employment resorted to theft and robbery. However, the main concern involved the spread of water-borne diseases, as water and sanitation demand outweighed the planned supply. Consequently, lack of access to water supply and the dearth of sanitation translated into deterioration of the overall urban waste management systems which was transposed into the planned sections of the cities as the excess population forced access through informal means (Smith, 2012).

During the past decade, Zimbabwe has undergone some economic melt-down (Nhapi, 2009). Subsequently, Harare City too has been devoid of the attendant planning for service delivery which was intricately intertwined with the national socio-economic and political uncertainties. In recent years, Harare City dominated the headlines of the waterborne diseases. Evidence of urban decay of the city of Harare is overwhelming, but the local authorities appear to have no alternative recourse as the total national circumstances dictate to their ability to formulate and implement recovery strategies. Inevitably, city authorities have continued to lack the ability to plan adequately for water supply and sanitation, leaving streets littered with waste, and drains in residential areas overflowing with sewage waste (Manzungu, 2012). The status quo of Harare City can in actual fact be alluded to the poor economic growth in the country, inadequate local governance and lack of political will which have overwhelmingly led to the collapse of the water and sanitation 
management systems (Chigonda, 2011). Notwithstanding the macro-variables that are at the core of the national challenges in Zimbabwe, it is the wanting local governance that explains the vogue of entitlement-mentality with which the excess population has sought to stake claims on and access to the urban infrastructure and services that appears to reasonably explain the spread of illegal and informal access to the formal sections of the city, thereby causing total collapse of the water and sanitation management systems. Perhaps, despite the popular rejection, the enforcement of the business regulation model of cost-recovery and payment for consumption could have served the purpose of local governance that is effective in service delivery. The free for all has allowed for the rate payers to abandon their civic responsibilities, thereby compounding the problems for local authorities and governance of the city infrastructure as well as the water and sanitation management systems.

Recent studies on the water and sanitation situation in Zimbabwe reveal that efforts to achieve the Millennium Development Goal (MDG) Seven (7) of reducing the number of people without access to water and sanitation by $50 \%$ in 2015, seem to be ineffectual (Chigonda, 2011; Manzungu, 2012). Moreover, results from the city of Harare's Water and Sanitation Inventory indicates that instead of noting improvements in the sector, the population that has access to safe water and sanitation declined from 81\% in 1999 to 51\% in 2009 (NationalWater and Sanitation Inventory, 2009 cited in Mangizvo and Kapungu 2010). Harare City with $16 \%$ of the national population makes a significant contribution to this degeneration of services, as rural migrants converge into the informal settlement around the periphery of the planned city.For that reason, it can be argued that the water and sanitation management system of Harare City have implications to the total national progress or regression in the attainment of the MDGs. Therefore, this paper provides an analysis of urbanization experiences in Harare City, Zimbabwe, in order to demonstrate the linkages with disruption of the urban water and sanitation management systems. The paper discusses the conceptualization of urbanization, urban water and sanitation management, as well as challenges in the developing world; and, it also provides an analysis of the recent water and sanitation situation in Harare City in order to demonstrate the need for business regulation model. For the latter, the paper discusses the legal framework that governs water and sanitation. Finally, the paper draws the conclusion that the weaknesses in the water and sanitation sector, precipitated by the dearth of local governance in the absence of an effective national social welfarist state, together with the unplanned creation of shanty towns around Harare City, compromise the quality of life of all city dwellers through, among other things, the proliferation of social ills and unhealthy conditions.

\section{Conceptualising Urbanization}

Urbanity can be described as a spatial concentration of people residing in an area, working in non-agricultural activities within a specified space, density and economic organization (Cohen, 2006). Thus, urbanization can be explained as the process whereby people move into these concentrated areas, abandoning their previously rural activities, through forms of rural-urban migration (Motta, Biagiani and Natalizia, 2012). Diverse arguments have been raised about the implications of urbanization, some highlighting its positive contribution to development whilst others claiming that it triggers social problems. On that note, classical economists' theories argue that inhabitants in rural areas are drawn to urban areas by the industrial wages (Smith, 2012). From the classical economist's view, industrialization is identified as the driving force behind urbanization. Moreover, the classical economists emphasize that people will continue to migrate to urban areas as long as their anticipated urban wages exceed their current rural earnings, if any. However, the urban bias theory states that the discrepancies in the welfare between urban and rural areas stimulate rural-urban migration and increase urbanization, which ultimately proliferate social ill-being and urban poverty (Minghong and Pelin, 2012). Nevertheless, in the face of the costs associated with urban expansion, the modernization theory views urbanization as a positive spectacle and upholds that it facilitates economic growth by increasing the modern-sector labor output in developing countries. Notwithstanding this glorification of urbanization, there is overwhelming evidence that the developing world's rapid rate of urbanization is associated with many social problems such as crime, unemployment, slums, and poor service delivery, which then questions the modernization theory's positive viewpoint (UNFPA, 2007).

\section{Urbanization, Water and Sanitation Management in the Developing World: An Overview}

In many parts of the developing world, urbanization and population growth are increasingly becoming challenges to governments, whose capacity to provide basic services for the urbanites is being compromised (Watson, 2009). According to the 2030 Water Resources Group (2009 cited in WHO, 2010), the forecast of water demand will over the next 25 years quadruple. Thus, the challenge is that the water and sanitation management systems are failing to keep up with the growing demand. Yet the provision of sufficient affordable water, safe accessible sanitation and ecologically 
efficient waste management is crucial to the health and well-being of urban city-dwellers (Smith, 2012). It is estimated that in African cities, individuals require 20-50 liters of water to ensure that basic needs of drinking, cooking and washing are met (Minghong and Pelin, 2012). Therefore, the challenge of access remains problematic as records indicate that about 884 million people in developing countries lack access to clean water (Jacobsen, Webster and Varairamoorthy, 2012). Together with this challenge, the provision of safe water and basic sanitation remains the core for achieving sustainable development (UNICEF, 2006), given the increasing concentration of people into the artificial landscapes of cities.

To highlight the intensity of population growth in developing countries' cities, it is crucial to note that whereas in 1990 Southern Africa cities' total population was 46.7 million, it was projected to reach 291 million by 2030 (UNICEF, 2006). The urban population growth rate in the developing countries stands at $3.9 \%$ per year and it is the highest in the whole world (UNFPA, 2007). Currently, 320 million people in the African continent live in urban areas, which is $37 \%$ of the whole African population and it is twice as many as was in 1990 (Agoramorthy, 2012). If the current urbanization trends continue at the same rate, projections are that by the year 2030, Africa's urban population will rise to about 654 million people (Smith, 2012). This trend of rapid urbanization can be expected to continue into the foreseeable future. Given this rapid rate of urbanization and the decaying conditions of most developing countries' cities, there exists a real threat to overstrain the already burdened water and sanitation management systems. As past experience has demonstrated, the result will be fatal water shortages in developing countries' cities. Considering that population projections for 2010-2030 also entail continued rapid urbanization, it is evident that developing countries' cities would not be able to absorb them productively. The UNFPA (2007) indicates that during the same 20 year period, the urban population in less developed countries is expected to treble. The present urbanization challenges for the water and sanitation management systems will persist.

The international community has however continued to initiate measures for assisting the developing countries in improving the living standards of the masses of people. Hence, the establishment of the Millennium Declaration in 2000 and the MDG efficaciously focused on the world's devotion and action on ending extreme poverty by the year 2015 . In addition, the Rio+20 Summit resolved to finish the work, and instituted a new set of goals, the Sustainable Development Goals (SDGs), with an all-inclusive approach encompassing economic development, social cohesion, environmental sustainability and good governance (Hutton et al, 2007).The United Nations (UN) MDGs of the year 2000, aimed to reduce by half the proportion of people without sustainable access to safe drinking water and basic sanitation by 2015 (Cheru, 2011). Granting that some parts of the world are progressing to meet the target, there are some disparities which are persisting in developing countries. Yet in the light of all these efforts, lack of access to safe drinking water and basic sanitation remains a hefty challenge in the third world. In Asia, an estimated 675 million people do not have access to safe drinking water; and, in Africa only $36 \%$ of the population has access to basic sanitation (Agoramorthy, 2012).

Minghong and Pelin (2012) point out that the greatest challenge that the developing world is facing in terms of development in urban areas can be termed the "Urban challenge", which is urbanization without development. They further discuss the significant characteristics of urbanization without development which are: (a) poor national economic performance; (b) lack of national policy that integrates economic and spatial planning; (c) relative absence of intermediate cities and market towns; (d), weak agricultural sector; and (e) over migration, leading to growth of mega-cities with poor economic bases and poor municipal capacity to provide the least possible basic services (Minghong and Pelin, 2012). From this observation, it can be asserted that investments in urban development and urban service delivery planning tend to overlook the national demographic dynamics as observed by Mota et al (2012), who posits that national economic growth and development is inadequate to meet the needs of the growing population in the third world.

\section{Typical City in Developing Countries}

Cities are the drivers of economic growth through manufacturing and services; hence, they attract large numbers of people and activities (Cohen, 2006), with the implications for increased demand for services. In developing countries, the capital city is usually the center of population, commerce and the nation's most powerful business with some significant industrialization (Watson, 2009). African cities are persistently growing against their economic status which is weakening continuously, leading to the corrosion in the supply of basic infrastructure and urban services, manifesting through interruptions in water and electricity connections, refuse collection, drainage clean up, and public roads maintenance. These impede urban productivity and negatively affect the wellbeing of urban residents (Cheru, 2011). It can be argued that the resources available at disposal for African cities cannot feasibly allow the implementation of coping strategies to deal with the growing needs and demand for services by the growing urban population.

As already stated, cities within the Southern African Development Committee (SADC) region are urbanizing rapidly 
(Jacobsen et al, 2012). Studies reveal that most cities in the SADC region have not been able to develop the basic utilities for services to keep pace with the rapid growth (Motta et al, 2012). In South Africa, theory shows that the urbanization challenge is aggravating the expansion of urban cities into mega-metropolitan cities which affects the quality of service delivery (Hutton et al, 2007). Projections made by the United Nations Development Program (UNDP) (2006 cited in the Water Operators Partnership (WOP), 2009), show that in Sub-Saharan Africa, they would only reach the MDG targets for water services by 2040 and for sanitation by 2076, demonstrating the depth of the problem associated with water and sanitation delivery in developing countries.

Given that cities are the focal points of industrialization, economic growth, innovation, and employment, the need to remedy the weaknesses of local governance of water and sanitation management systems is imperative. Cities in the developing countries have great potential for economic and social development. Empirically, in as much as African cities have the potential, most of them have not realized the ambition to become magnets of social progression, economic growth and transformation engines (Hutton et al, 2007). A recent world development report indicated that instead of cities fostering economic growth and transformation, they are rather part of the cause and main indicator of the economic and social crisis that have tormented Africa and the developing world (Watson, 2009). Inevitably, the need for more scientific knowledge and technical expertise to convert the cities' potential into reality, as well as "ability" to formulate and implement comprehensive urban policies successfully, is of great urgency. African nations have expressed a need for a shared covenant to address its problems through more scientific knowledge and have formulated an urban strategy, the New Partnership for Africa's Development (NEPAD). Through NEPAD, Africa aims to influence the development of sound public policy by promoting research and the application of science, whose results will address the challenges facing African cities (Motta et al, 2009).

Urban studies have shown that sound governance and management of urbanity is central to the cities' capacity to become realistic engines of prosperity and better standards of living (UNFPA, 2007). To this extent, cities in developing countries can live up to their expectation as expressed by classical economists that people are ordinarily drawn to cities by the opportunities for better earnings. Perhaps this can justify the reason why African cities are growing fast. On that note, the question which can then be raised is what is it that can be done to strike a balance between the urbanization rate and the supply of services in urban areas so that all inhabitants can enjoy the bliss of living in the cities. For now, the paper turns to Harare City and Zimbabwe to draw some empirical evidence to illustrate that the collapse of water and sanitation management systems tends to engulf developing countries' typical cities in protracted social ills.

\section{Background of the City of Harare, Zimbabwe}

Harare is the capital city of Zimbabwe situated in the North-Eastern part of the country with an elevation of 1483 meters and its climate is described within the warm temperate category (Zimbabwe Parliament, 2010). Harare's average annual rainfall is estimated between $825 \mathrm{~mm}$ and $855 \mathrm{~mm}$, and it has 3 seasons; winter, summer and rainy seasons. As the capital city, it is the country's commercial, administrative and communications center (figure 1).

Figure 1: Map of Zimbabwe, geographic location of Harare City and share of national population

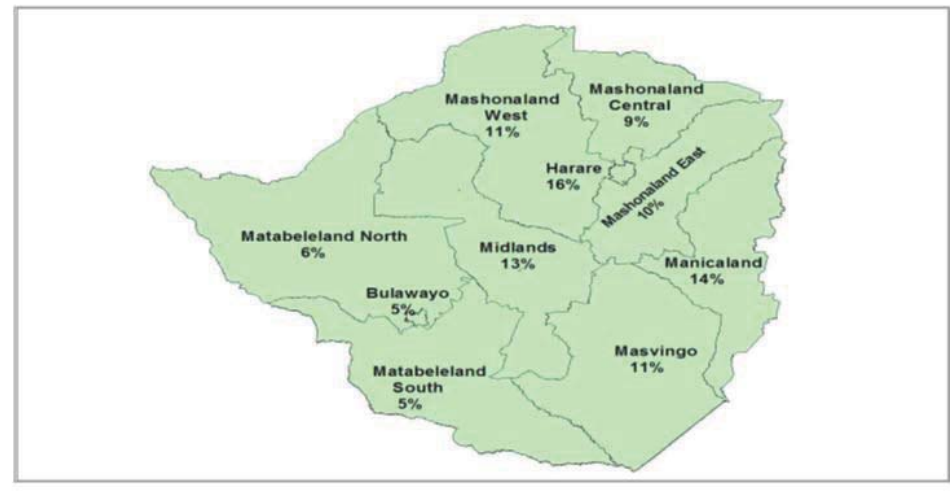

Source: Zimbabwe Central Statistics (2012 
Administratively, Harare is independent as a province on its own (Zimbabwe Parliament, 2002). For these reasons, as well as the historical background that it was once the engine of regional growth in Southern Africa, Harare City has continued to raise expectations of a better life among the rural people to the extent that rural-urban migration has continued, notwithstanding the apparent struggles.According to the August 2012 population census, the city has a total population of over two million, which consists of $16 \%$ of the country's total population (figure 2). Indeed, the city of Harare is the most populous and densely populated in Zimbabwe; and, the average city population growth rate has been 6-8\% since 2000. Harare City consists of 46 wards and a total of 503276 households, with a density of 2406 persons per square kilometer (Zimbabwe Central Statistics, 2012).

Figure 2: Total official population of Harare City, 2002-2012

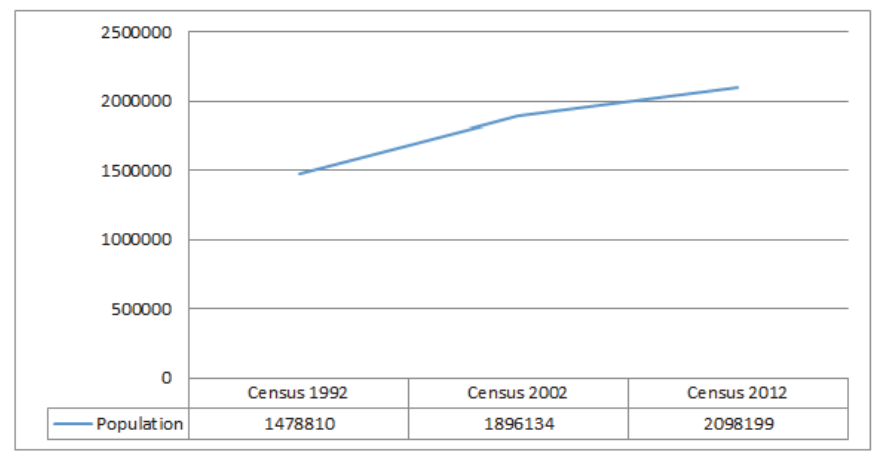

Source: Zimbabwe Central statistics (2012)

Harare City is situated upstream of the Lake Chivero dam from where it extracts water to service its population (Water Operators Partnerships (WOP), 2009). Lake Chivero dam, located 35km South-West of Harare City, is designed for a full capacity surface area of 26.5 square kilometers, a volume of $247,181,000$ cubic meters and a mean depth of 9.3 meters, with the deepest point of 27 meters (WOP, 2009). The Lake overflow level is at 1,368meters above mean sea level and receives water from the following three major rivers: Manyame, Mukuvisi and Marimba. There are five waste water treatment works and two water treatment works within the Lake Chivero dam catchment. Harare City Council is responsible for all the treatments and supplies; also, it plays a key role in the management systems (WOP, 2009).

\section{Urbanization Challenges in the Water and Sanitation Sector of Harare City}

Evidence collected in 2011 from several suburbs and informal settlements of Harare City, including Kambuzuma, Mbare, Epworth (informal settlement), Budiriro, Highfield and Sunningdale demonstrate conclusively that the water and sanitation management systems had collapsed. For ethical reasons, the persons who appear in the photographs were requested that their images be used in the scholarly work being reported in this paper.The failure of the water and sanitation management systems in Harare can be attributed to the archaic infrastructure which is still being utilized in the sector. The city of Harare was established in 1890, Fort Salisbury by then. Harare City Council has not been able to replace most of the aging water pumps, pipes and motors, which have been operated without adequate maintenance even after their lifespan lapsed (Zimbabwe Parliament, 2002). The consequences of the aging infrastructure and lack of maintenance is apparent in the malfunctioning of the water distribution and sewage systems, as demonstrated by the broken sewage pipe and tank as well as overflow in the streets of Kambuzuma (figure 3), Budiriro (figure 4) and Epworth (figure 5). In the city, there are more of such broken sewage pipes, with overflow of sludge onto streets in residential areas, which cause respiratory complications, especially in densely populated informal settlements (figure 5). As a result, the city water systems are decrepit and will continuously collapse and this translates into water shortages (Reuters, 2007). 
Figure 3: Broken sewage pipe in Kambuzuma suburb of Harare City, 2011

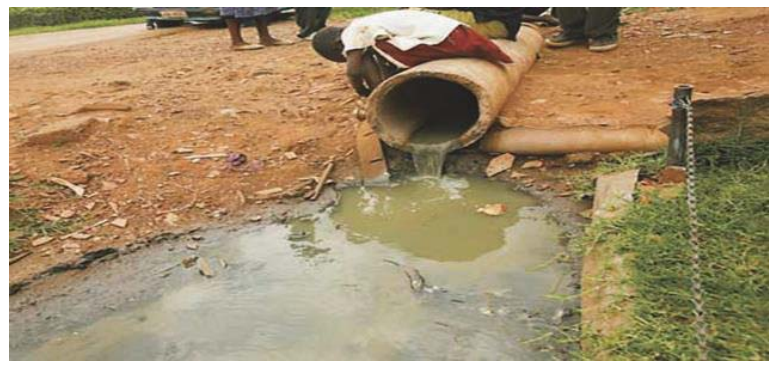

Figure 4: Burst sewage tank in Budiriro suburb of Harare City, 2011

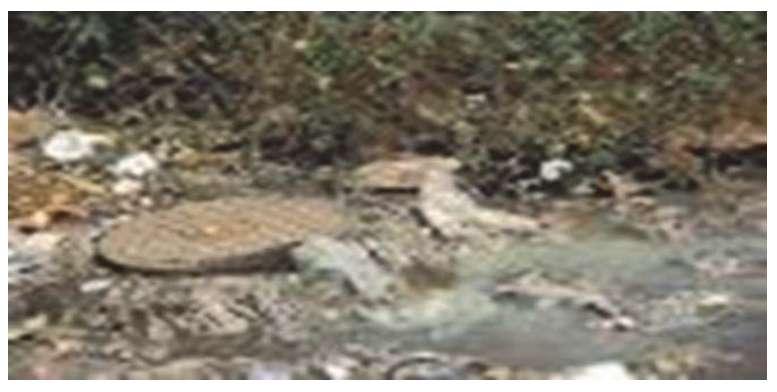

Figure 5: Sewage collecting in the residential area of Epworth Informal Settlement in Harare City, 2011

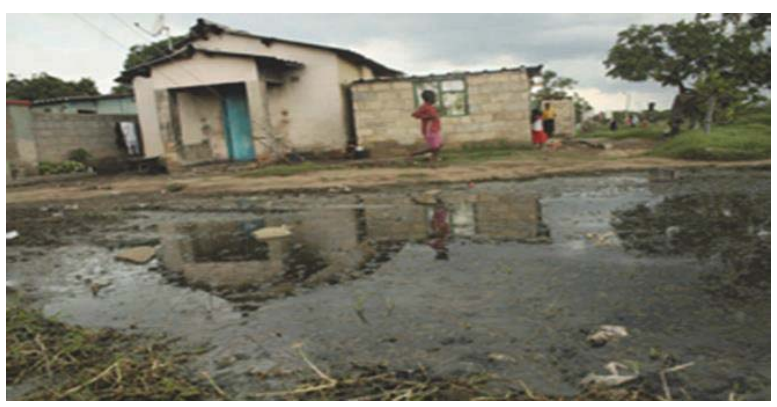

The local governance's incapacity to enforce cost recovery for water and sanitation services consumption is often regarded as the chief contributory factor to the inadequacy of urban water management in Harare (The Herald, 2010). The capacity of the water and sanitation management institutions is compromised due to the lack of will of service recipients to pay for the services rendered to them, hence, the failure to increase service coverage and delivery. Instead, the majority of residents queue for hours to draw water from free supplies (figures 6 and 7), demonstrating a determination to consume services for free. Even in a case where the supply is not adequate, residents persist (figures 6 $\& 7)$. 
Figure 6: Harare City residents queuing for water in Highfield suburb, 2011

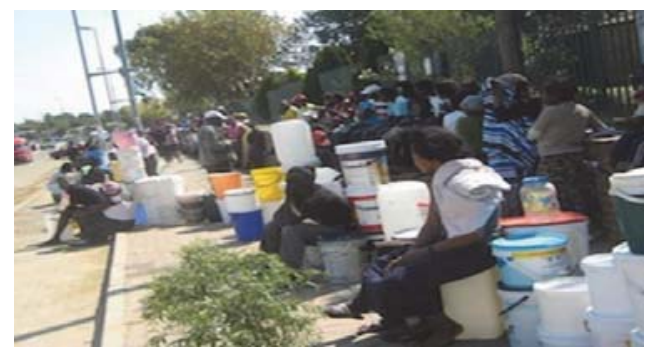

Figure 7: Harare City residents queing for water in Sunningdale suburb, 2011

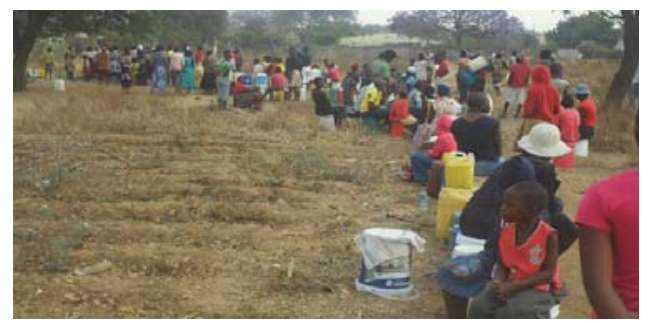

The same tendencies are reflected in the waste dumping on the streets. Whereas residents cannot provide waste removal services, the manner in which even those who have the means of dropping waste in the official dumping site can willingly dump in the streets within populated areas is indicative of the challenge that the local government is facing. The conditions of living are unbearable. Combined, the smell from sewage overflows and that from the unofficial street dumps can be expected to present serious health hazards. Sunningdale (figure 10) suburb has several unofficial dumping, which is typical of almost all the suburbs in Harare City.

Figure 8: Uncollected garbage in Mbare suburb of Harare City, 2011

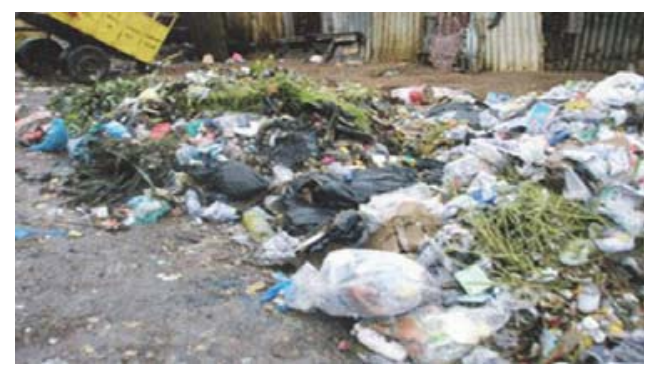

Figure 9: Uncollected waste in Epworth suburb of Harare City, 2011

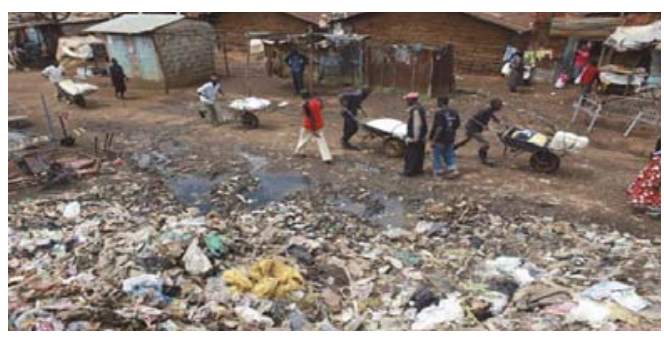


Figure 10: Street dump in Sunningdale suburb of Harare City, 2011

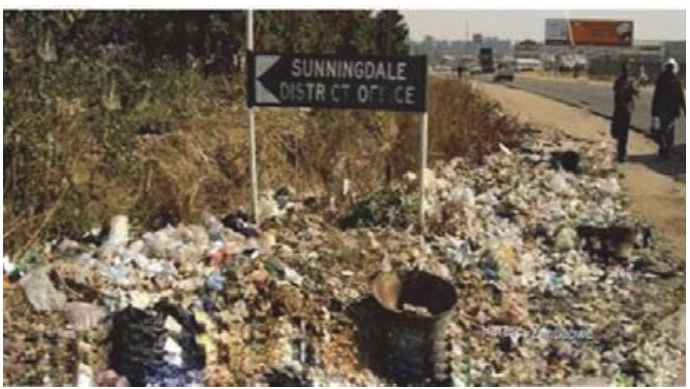

The evidence reviewed above entails characterization of the local government as a collapsed authority because it seem to have no means of dealing with the challenges. Whereas the photographs were taken in 2011, there were reported cases of typhoid within the Harare City's high-density residential areas of Kuwadzana, Dzivarasekwa and Budiriro districts in 2012. Diarrhea and dysentery are the talk of the city in local clinics and hospitals, especially amongst children below the age of 5 years. That is, the challenges of water and sanitation in Harare City are evidently matters of the present and future, rather than the distant past.

Moreover, the urban water and sanitation systems depend on the availability of funds and proven methods of costrecovery. It can be assumed that residents are willing to pay for the services consumption, but they tend to be reluctant due to the fact that the water supply is scarcely available and garbage waste is rarely collected. The common reasons for not paying for services consumption among city dwellers are associated with the lack of reliability of supply, when nonpaying informal settlements have perfected their irregular and illegal access. The Herald (2007) newspaper reported that local municipalities embarked on cutting-off supply to all the households that do not pay their water bills, which contradicts Government's standpoint that despite failure to pay, all residents are entitled to access to water supply and efforts to lessen the payment burden through installments. However, the local municipality has persisted with their actions because it is in dire need for a sound financial base to continue servicing the rest of the population, efficiently and effectively. Simultaneously, the masses of urban dwellers are either unemployed or underemployed and they cannot afford to pay for their services consumption. Evidently, there exist no business model that can allow for benefits of both words where the income-less people are served and the costs for repairs and maintenance are recovered. Local governance of the city would almost collapse without funds to maintain the water and sanitation systems. Forfeiting payment has a negative implication on the efficiency of water and sanitation service delivery because rates and taxes are the source for the municipalities' funds (Manzungu, 2012). Given the national government's financial crisis, the Harare City Council would also be in serious financial distress without an effective model of cost recovery. In support of the local municipalities' stance, major development agencies such as the World Bank have bandied the economic concept of willingness to pay for water so as to enhance better services and therefore, eventually, residents are obliged to pay. That is, whereas it is understandable that poor people living in unplanned parts of the city need to be catered for their water and sanitation need, and given the pressures of the MDGs, Harare City Council would still be hamstrung to find funds to deliver such services. The challenge of such interventions would be to fuel the perceptions in rural areas that migrating to the city is the key solution for upward social mobility. Often, economics seeks to manage scarcity through recovery of the cost of consumption.

Manzungu (2012) finds that in as much as there are external forces that hinder the efficiency in service provision there are also internal forces within the local municipalities that affect the effectiveness of service delivery. Togarepi and Tsiko (2012) argue that urbanisation is not the problem, but that the weak institutional, administrative, financial and managerial capacity is to blame. These authors assert that local municipalities are failing to meet the demand of services in urban areas because, in part, their plans are rigid and cannot adjust to changing population trends. Mangizvo and Kapungu (2010) found that municipalities in Zimbabwe do not possess the powers that allow them to make decisions in critical areas that affect urban infrastructure development; yet, they shoulder the blame for not fostering improvements in service delivery and urban economic development.In practice, local authorities depend to a large extent on central government transfers, which rarely increase in proportion to demographic growth, thus contributing to declining municipal revenues and expenditures in per capita terms. But this heavy dependence on national government transfers has also thwarted the independence of local governments. As a result, local government's capacity for planning, implementation, 
environmental management and provision of services as well as recovery of costs of consumption, is eroded or nonexistent.

According to Manzungu (2012), the relationship between urbanisation and unemployment, informal settlements and the ills associated with water and sanitation is evident. Smith (2012) shows that the unemployed population that migrate to urban areas in search of jobs tend to fail to secure employment, thereby living in squalid condition as they cannot afford basic accommodation. Consequently, the rise of informal settlements in urban areas is a huge constraint to the municipal service delivery system. The informal settlements are not included in the municipal budget and they are characterised by lack of water systems, mountains of stinking garbage as there are no roads for the garbage disposal trucks to collect the refuse; and, almost all of them did not have electricity supply.

\section{Consequences of Urbanization on Water and Sanitation in Harare}

The socio-economic problems currently facing the city of Harare are mainly caused by the increasing population which exerts pressure on industry and social services. The problems extent to a wide array but are predominantly spotlighted upon squatter settlements, waste management, water and sewer systems as well as unemployment which causes a rise in urban poverty (which is claimed to be the breeding grounds for crime) as well as urban agriculture that demands for even more water availability (Mangizvo and Kapungu (2010). Such problems compound the challenges of piling-up of uncollected garbage (figures $8,9 \& 10$ ), bursting of sewer pipes and tanks (figures $3,4 \& 5$ ) as well as persistent water shortages/rationing. The provision and availability of water determines the wellbeing of the residents; and, lack-thereof results in people resorting to unsafe water sources which are exposed to contamination from human excreta, especially under the circumstances where residents use the bush-system for toilets which are closed because of lack of water. Conditions such as these lead to the outbreak of water-borne diseases like cholera, diarrhea, dysentery and typhoid. The outbreak of cholera during the 2008-2009 period which claimed a total number of 4300 deaths and 100000 cases were mostly in Harare City (Togarepi and Tsiko, 2012).

Solid waste generation increases with population growth and industrialization. In Harare City the waste management system is generally weak as indicated by Togarepi and Tsiko (2012); and, that garbage collection is pragmatically non-existent in residential areas (figure 8,9 \& 10). According to Practical Action (2010), waste management systems should encompass both urban solid and hazardous waste streams, entailing dealing with problems of waste prevention and collection, recycling, composting, incineration, and landfilling. The World Health Organization (WHO) (2010), appeals for the combination of the afore-mentioned activities to promote healthy communities and a safe environment through Integrated Solid Waste Management. In Harare City, the situation is rather despicable as streets are having piles of garbage and uncollected waste (Togarepi and Tsiko, 2012). Chigonda (2011) identifies several factors that hinder the provision of adequate water and sanitation in Harare City as economic decline, poor local governance structures, political interference, corruption, population growth, dilapidation in water supply infrastructure, and absolute disregard of water quality standards and laws. This paper will focus on the governance systems only, as it reflects on the ability and/or capacity of the local government to take remedial action.

\section{Zimbabwe's Former "Sunshine City"}

The city of Harare was in the past commonly known as the "Sunshine City" because of the efficacy of its service delivery systems. However, due to the problems associated with politics and the downfall of the economy, the city's water and sanitation structures are dilapidated. On the $23^{\text {rd }}$ of May in 2009, the local newspaper, Zimbabwean Independent, desolately reported in its editorial section that the city has turned up-side-down from "Sunshine City" to a "Sewage Farm". Sanitation services in Harare barely cover the whole city due to the geographic territory, urban sprawl and population density. The emerging informal settlements, such as Epworth, do not have access to basic sanitation services, most residents there use self-built pit-latrines whilst some resort to open defecation which is a health hazard. Furthermore, the overall sewerage system is virtually dysfunctional. Thus, Mangizvo and Kapungu (2010) posit that the floating of sewage waste is a common feature in the western high density suburbs of Harare City.

The level of access to sanitation in Harare City is very low. Consequently, between 1-33\% of households have flush toilets which discharge to sewers, septic tanks or open drains which pose a health hazard. Amongst all the households in Harare, between $23-37 \%$ have Blair latrines, $24-48 \%$ have sanitary pit latrines and $2-13 \%$ have no toilet facilities at all and they share with their neighbors (Togarepi and Tsiko, 2012). It is of extreme importance to bring to awareness that Harare City's main sewage treatment amenities discharge exonerates to rivers draining to Lakes Chivero and Manyame, which are the city's prime sources of water. Therefore the cholera outbreak of 2008-2009 can be 
attributed to the infirmity of discharging sewage waste into water resources, where-for the country has not been able to source adequate water purification chemicals because of the economic crisis and, perhaps, international sanctions placed against it.

\section{The Legal Framework for Water and Sanitation Management in Harare City}

The Harare City Council operates under the Urban Council's Act of (Chapter 15:29) complimenting it with the Water Act of 1998 (Hove and Tirimboi, 2011). The management of urban areas in Zimbabwe is governed by the Urban Councils Act Chapter 29:15 and part xiii: 183 relate to the water supply services in urban areas (National Urban Councils Act, 2002). The responsibilities of the Council in terms of the provision and maintenance of supply of water within the council area are specified within the clause. In assessing the Urban Water Act, there are quite a number of weaknesses which can be identified. The Urban Act does not provide ample regulations on the management of urban water supply service; instead, it is just a large document without authentic contextual coverage on the management of water supply systems. The minimal information ascribed in the clause does address details on issues such as the water tariff setting procedures but there is no distinct designation of responsibility upon the regulation of water management systems in urban areas.

Remarkably, other Southern African countries such as South Africa and Zambia have specific Urban Water and Sanitation Acts, which plainly clarify all the institutional arrangements in urban water management services (Watson, 2009). Conversely, it is a different case for Zimbabwe which does not have a specific policy on urban water services. Although efforts to establish one were made in 2004, only a draft on urban water policy was prepared and it was amended in 2007 but was never finalized; hence, the country does not have a water policy document (Nhapi, 2009) to date. The Zimbabwe National Water Authority (ZINWA) Act of 1998 is an organizational based statute and provides guidelines about the catchment management rather than the urban water management systems (Chigonda, 2011). The ZINWA Act also lacks clarity on the role on ZINWA in relation to urban water management. On the other hand, in circumstances where ZINWA is managing urban water services, there is no other organization which oversees its operations, which suggests that ZINWA manages itself and leaves room for loopholes as there is no one to evaluate its performance.

\section{Conclusion}

The management of water resources and supply is essential to the development and growth of cities. Sustainable resource use and the provision of quality services to a growing urban population reinforces the success of urban management, enables them to act as poles of economic growth, and is at the core of social and economic development in an urbanizing world. Addressing Africa's urban water challenges will significantly improve the ability of cities to maximize their economic growth and mitigate the social-ills inhibiting the welfare of urban habitants. Urbanization is seen as defying the improvement of water supply and sanitation services which are central to economic growth and to the achievement of the Millennium Development Goals. However, sustainable provision of water and sanitation services may require new approaches to the planning and financing of service delivery.

Therefore, the paper concludes that investment in urban planning lags behind demographic growth and urban service delivery planning is branded by inconsistencies within the water and sanitation management systems. Harare City Council's failure to manage the urbanization trends can be attributed to the economic and political crises. However, the lack of urban policies in Harare City andthe institutional weaknesses of the legislation governing water and sanitation management systems are central to impairing ability of a full designation of the management etiquette; and, the uncultured discharging of sewage into some of the rivers that are within the catchment of the principal water resources supplying Harare City, conclusively negate all the efforts indebted to improving the service conditions. Thus, this paper identifies the ambiguities of the urban residents in terms of their apparent intent for consumption of free goods and services, local government's relationship with the national as well as the legal limbo on water and sanitation governance, as the most evidentfactors associated with Harare City's on-going abyss in service delivery. The proliferation of social-ills is a mere symptom of a deeper problem. There is need for further conduct applied research in order to gain more insight and further appreciate the challenges that local governance is faced with in its search for a business-like model for the improvement of water and sanitation management system in cities such as Harare. 


\section{References}

Agoramorthy, G. (2012). "The global sanitation crises: can it be tackled?"American Journal of Social Issues and Humanities 6: 25-35.

Cheru, G. (2011). "Costs and service levels of water and sanitation."Journal of Sustainable Development in Africa 10 (2): $156-174$.

Chigonda, T. (2011). "Water supply and sanitation in the new residential areas in new Zimbabwean towns." Journal of Sustainable Development in Africa 12 (3): 349-362.

Cohen, B. (2006). "Urbanization in developing countries: current trends, future projections and key challenges for sustainability."Technology in Society 28:63-80.

Hove, M. and Tirimboi, A. (2011). "Assessment of Harare water service delivery." Journal of Sustainable Development in Africa 13 (4): 61-84.

Hutton, G., Haller L. and Bartram, J. (2007). Economic and health effects of increasing coverage of low cost household drinking-water supply and sanitation interventions to countries off-track to meet MDG target 10. Geneva, Switzerland, World Health Organization. Retrieved on 12 June 2013 from http://www.irc.nl/page/38443.

Jacobsen, M., Webster, M. and Varairamoorthy, K. (2012). "The future of water in African cities."International Journal of Water Management 3: 46-85.

Mangizvo, V.R. and Kapungu,N. (2010)."Urban domestic water crisis in Zimbabwe."Journal of Sustainable Development in Africa 12 (2): 254-262.

Manzungu, H. (2012). "Can collective action lead to sustainable outcomes in the provision and management of domestic water in Zimbabwean urban areas?" Journal of Sustainable Development in Africa 5 (5): 122-135.

Minghong, T. and Pelin,W. (2012)."Challenges for sustainable urbanization: a case study of water shortage and environment changes in Shandog China."Procedia Environment Sciences 13: 919-927.

Motta, G., Biagiani,A., Baglioni, G. and Natalizia, G. (2012)."Diversity in Public Research."Journal of Social Sciences 3 (12): $276-287$.

Nhapi, I. (2009). "The water situation in Harare, Zimbabwe: a policy and management problem."Water Policy 11:221-235.

Practical Action. (2010). Low-cost sanitation technology - Zimbabwe.Retrieved on 12 June 2013 from http://practicalaction.org/ practicalanswers/product_info.php?products_id=408\&attrib=2.

Reuters(2007).Untreated sewage polluting Harare water supply.Retrieved on 11 June 2013 fromhttp://www.reuters.com/article/ idUSL15247637.

Smith, W. (2012). "Urban development imagination." InternationalJournal of Development 5(1): 53-80.

The Herald. (2007).Sewage Management: Challenges and Solutions. Retrieved on 12 June 2013 fromhttp://allafrica.com /stories/200703140171.html.

The Herald (2010).Harare Sewer Plants' Rehabilitation Underway.Retrieved on 12 June 2013 fromhttp://allafrica.com/ stories/201003080378.html.

Togarepi, S. and Tsiko,R.G. (2012)."A situational analysis of waste management in Harare, Zimbabwe."Journal of American Science 8 (4): 692-706.

United Nations (UN)(2006). Millennium Development Goals Report.Retrieved on 10 June 2013 fromhttp://unstats.un.org/unsd/mdg /Resources/Static/Products/Progress2006/MDGReport2006.pdf.

United Nations Childrens' Fund (UNICEF) (2006). The state of the world's children.Retrieved on 11 June 2013 fromhttp://www.unicef. org/publications/files/Child_Protection_Information_Sheets.pdf.

United Nations Population Fund (UNFPA)(2007). State of the World Population: Unleashing the Potential of Urban Growth. Retrieved on 10 June 2013 from http://www.unfpa.org/.../site/global/.../2007/695_filename_sowp2007_eng.pdf.

Watson, V. (2009). "Seeing from the South: refocusing urban planning on the globe's central urban issue."Journal of Urban Studies 46 : 2229-2275.

World Health Organisation (WHO) (2010).Joint Monitoring Programme for Water Supply and Sanitation.Retrieved on 10 June 2013 from http://whqlibdoc.who.int/publications/2010/9789241563956_eng_full_text.pd.

Water Operators Partnerships(2009).Africa Utility Performance Assessment.Retrieved on 12 June 2013 from http://www.wsp.org/User Files/file/WOP_Report.pdf.

Zimbabwe Independent (2009).Harare once a "sunshine city" now a "sewage farm".Retrieved on 13 June 2013 fromhttp://allafrica.com/ stories/200901300586.html.

Zimbabwe Central Statistics,(2012).Zimbabwe Census Report. Harare: Government Printers.

Zimbabwe Parliament. (2010).National Water and Sanitation Inventory.Retrieved on 10 June 2013 from http://www.iwawaterwiki.org/ xwiki/bin/view/Articles/16)+HARARE+(Zimbabwe)+3.

Zimbabwe Parliament, (2002). Urban Councils Act No. 15:29.Retrieved on 12 June 2013 on www.parlzim.gov.zw/attachments/ article/116/COUNCILS_ACT_29_15.pdf. 